\title{
Someone Has to Tell These Children: "You Can Be As Good As Anybody!”
}

\author{
Cecilia Fiaka
}

\section{INTRODUCTION}

I hail from Ve-Agbome in the Volta Region of Ghana. I grew up in the 1960s in a farming community and completed Elementary School Form Four there. At age 15, I was sent off to Accra to work as a house help to save some money to support my mother and continue my education.

\section{Coming to Accra}

When I was ten years old, a lady moved into our house with her son, who happened to be my father's child. This lady became a permanent member of our household and a second wife to my father, which was very uncomfortable for my mother and my siblings. This led to the marriage between my parents hitting the rocks, and my mother had to move to her parents' home with four of my younger siblings, leaving my elder brother and I to stay behind with my father and his new wife. My brother and I were left

\author{
C. Fiaka $(\bowtie)$ \\ Nneka Youth Foundation, Tema, Ghana \\ e-mail: cecilia@nnekafoundation.org \\ (C) The Author(s) 2020
}

M. L. McLean (ed.), West African Youth Challenges and

Opportunity Pathways, Gender and Cultural Studies in Africa and the Diaspora, https://doi.org/10.1007/978-3-030-21092-2_7 
behind because my mother felt the two of us could manage ourselves, as we were a bit older. I was ten years old at that time.

My brother and I were maltreated and most of the time slept with an empty stomach because my stepmother would not feed us. My father, even though he was a teacher, had taken to drinking and could not see what was happening to us. As a result of the conditions under which we were living, my brother was sent to boarding school, and immediately after I finished elementary Form Four, when I was 14 years old, my mother sent for me to come back to her. Knowing what my mum was going through to pay for my elder brother's secondary school—she had to pay his school fees all by herself-I did not have any hope of continuing my education any time soon. My mum felt bad about keeping me at home for so long while my brother completed school, so she decided to send me away to work as a house help.

One early Tuesday morning, she woke up and called me to her side, as we were all sleeping in the same room. She said she had discussed with a cousin of hers a plan to take me to Accra to work as a maidservant-a "baby nurse," as it was called in those days. I thought I was having a bad dream. All that came to my mind was that I was finished. I was young and immature, but I knew a few people from my area who grew up in that job, or did it for a long time, and none of them was able to achieve much as adults. I could not imagine how my dream of becoming somebody was going to be fulfilled as a baby nurse.

Hearing that message from my mother that fateful morning, I broke down in tears. Seeing me in that state, my mother also broke down. "Ceci," she called over and over again before I could respond. She tried to comfort me by saying that she would ensure that I would be able to continue my education after one year of employment. "Child," she said, "I trust you. I know you are a good girl. But staying in the village for such a long time without doing anything meaningful would be frustrating. You might end up getting pregnant, for the devil finds jobs for the idle hand and mind." I quickly sat up, wiped my face, and became interested in what she was saying, as I did not want to become a mother at the age of 15 .

My mum told me that an auntie was in town for a funeral and was going to go back to Accra on the following Monday morning, so I should prepare to go with her. The day came for me to leave home. With my auntie and my mother walking beside me, tears flowing, I carried my small woven rubber bag to the roadside to look for a trotro to go to Accra. Standing there on the roadside, it dawned on me that a new life had begun 
for me, a new chapter had been opened, and the sooner I stopped thinking negatively and started living that chapter, the better it would be for me.

It was not a journey of no return. It was going to be for just one year. I trusted my mother to fulfill her promise to me. With these new thoughts, I started enjoying the journey-admiring the various towns and countryside along the way. It was my first time traveling that kind of long distance. My auntie would ask once in a while, "Are you sleepy?" or "Are you tired?", and I would answer, "No." So she said, "Keep watching things on the road." She pointed out places of interest like the Adome Bridge, which I had read about it in a textbook but was now actually seeing for the first time. It took us more than six hours to get to Accra.

I stayed in my aunt's house for just one week before she made arrangements for me to move in with the family I was to work for. I was told that, due to the stubbornness of the children - two boys, 5 and 7 years old - no maid had survived more than three months with that family without either leaving or being sacked. The madam I was to serve was a white lady, and the husband was a black Ghanaian. I counted myself lucky because it was a prestigious thing to have whites as your employers. After agreeing on how much I would be paid, my auntie left me alone with the family. I was shown my small room-the storeroom to the main house that was not being used for that purpose. Although the room was small, it was more than enough for me. But I had mixed feelings because it was my first time being alone in a bedroom.

I quickly adjusted my thoughts and told myself that I would try, no matter how difficult, to stay with this family for the one year I was there to work, and nothing was going to make me fail. To encourage myself, I recited my mother's words to me: "I gave birth to you, and I know that you, Cecilia- even if they put you in the lions' den, you could cohabit with the lions and they would not hurt you." I became stronger by the day when I remembered my mother's words, such as "I trust you, you are a good girl, and I do not want you to become a spoiled child," and the like. This experience taught me what a potentially powerful impact parental encouragement can have on children.

The boys became my kid brothers as I was only 15 years old myself. I was put in charge of all the household chores, including cooking, washing, and ironing. Chaamber, the garden man, only came to weed and tidy up the garden in the afternoon. He was a good man. He would sometimes help me with the ironing. The boys were very strong, and one really needed to be tough to manage to stay with them. My madam, Mrs. White, 
liked me very much because she realized I loved the boys so much. I was treated very well by the family, though there were times I felt I was truly a maidservant. For example, I was not allowed to eat at the table with them, and I only ate after they finished their meal. There was no way I could sit to watch television with them in the living room. Also, I now realize that the workload given to me was too much for a child my age.

The reality of having to learn how to cook the white man's food hit me when, barely a week into the job, I was asked to prepare lunch for the family. I had no option but to prove myself. However, I really did fail. I opened a full 600 grams of tomato paste for a small meal. My madam, who was a designer-she designed clothes for the former First Lady, Mrs. Faustina Kutu Acheampong-had a lady apprentice who was learning how to sew with her, and that lady came to rescue me. She taught me what to do next time when preparing such a meal. Another time, when I was washing the dishes, due to a little carelessness the whole rack fell and I broke all the glasses, plates, and bowls. I broke down weeping thinking that was going to be my end in that house, as I thought there were no other bowls to be used. My madam came out from her room to console me and later brought a new set of plates and bowls to replace the broken ones.

My master drove past El Wak Stadium every day to work and could buy newspapers for himself on the way, but I had to wake up early in the morning and walk almost two kilometers to El Wak Stadium to buy newspapers for him. That was how I started every day. One morning, something happened that I never forgot. That day the newspaper vendor was delayed, so all of us, especially the regular customers, decided to form a queue while waiting. Just as he arrived, the queue jammed up as everybody was in a hurry to go to work. As we struggled to get the papers, I felt a stinging slap on my ear that stretched to my eye. It came from a navy man who claimed I had crossed him. I could not believe such a thing could happen to a poor girl like me. Onlookers just shouted, "Oh!" And that was all they could say, because who were they to challenge a navy man? I left the place without the paper, and by the time I got home my eye was red and swollen. By the time my master drove me in his blue Datsun 120Y to the spot, the gentleman had left. To this day, the sight of a navy man in white drives me mad.

Despite the self-pity I felt about working as a maidservant rather than attending school, which I now realize there should not have been the need for, I also had good moments with the family. I was exposed to several beautiful things, I learned so much, and my desire to make it in life became 
stronger. They took me everywhere with them, and when the boys enjoyed popcorn or ice cream, I enjoyed it too. At the Russia Cultural Centre, for the first time in my life, I watched a movie on a large screen. We did this almost every weekend, and we had this opportunity, which existed only for Russians, because my madam was Russian. I had a lot of fun with the boys, from climbing trees to riding a bicycle. I once fell from a mango tree and still have the scars on my belly to date. I could not complete my bicycle riding lessons because I fell once during the exercise. Despite these activities, my skin color still made me feel I was a maidservant most of the time.

The children would confide in me as a true sister even though they infuriated me sometimes. They sometimes soaked their pillows, jeans, shorts, and towels in their bathtub, which I had to take care of. They dropped toys and many things in their toilets, which I had to remove with my hands. They were very daring, and some of their plans I could not keep secret-I had to tell their parents in confidence for guidance. But no matter how troublesome they were, I was able to manage that which most people could not.

Most evenings I had to walk back to El Wak Stadium to buy kenkey (a local food made from corn dough) for the family and the dogs. I really developed a love for dogs while in the house of the Whites and nurtured the desire to own and keep them when I became somebody. Strong desires that are not relented yield success. I currently own many dogs, and I can proudly say that being a maidservant taught me many lessons in life and made me a stronger person. I named my first dog after their dog, Skippy.

After about eight months of my stay with the family, the unexpected happened. The marriage between the couple hit the rocks, and my madam had to return to Russia, her home country. She wished I could go with her, but that was not possible. She gave me wonderful gifts, like a Pronto wristwatch, a ring, and clothes, among others, and asked me not to leave her children alone. At that point in time, I became like a mother to the boys. The White family became my family and remain so to this day.

As the days went by, I was counting when the one year was going to be up so I could continue my education. The time finally came for me to leave. I collected the little savings I had made during the year and went to the market to buy a few things for school. The rest I reserved for my mum to supplement my school fees. I finally bid the White family goodbye and returned home. They were sad to see me off. My master assured me that they would always receive me as part of the family should I return to Accra anytime in the future. 


\section{RETURNING TO THE VILLAGE}

After I got back home to the village, my father sent for me. "I have heard that you returned from Accra, and I hope this is the best time for us to discuss your going back to school." This was my father's welcoming address when he saw me for the first time in close to two years. He had just been transferred to our village to continue his teaching career, which was nearing retirement.

I was excited, and I thanked him because I thought I saw repentance on his face. I thought he really regretted what he had done to me before I left for Accra. He always told me, "Cecilia, you are a very determined girl, and I know you would go places if you do not relent." We discussed which school I could possibly go to at the time, since my last Common Entrance results had expired and could not be used. He had agreed on the date we should travel to Kpando in the company of his wife and the children to look for the school. I bade them good day and left for my mother's house.

"Ceci, Ceci!" I heard someone calling from behind. I turned only to see my aunt, my father's sister, on the main road on which I was walking back home. She had come out from my grandfather's house by the roadside. "I would like to have a word with you," she said. "I heard your father says he is planning to send you to school; but you know what, he just returned home with so many children, and he has no farm to start feeding them yet. Your going to school under your father's care is not going to be possible. Why don't you go back home to tell your mother to enroll you to learn how to sew? Your mother has a sewing machine and is better able to take care of you than your father."

Again, I thought I was having a bad dream. My father and I had discussed going back to school not quite ten minutes earlier. The only people present were my stepmother and her children. How did the news get to my father's immediate younger sister?

"I knew it! I knew it" my mother exclaimed when I told her. But I retorted, "Since it is not my father who said this, let us give him the benefit of the doubt."

A few days later, my father called me and said I should prepare so that we could go and look for a school. I prepared, and one early morning we took off to Kpando. We went to the Secondary, the Technical, and the Commercial schools that were there, but as I could not use my previous Common Entrance results to enter the Secondary and the Technical, we 
had to settle for the Commercial school, which was a private school. I told myself that, wherever I find myself, I can make it with all my determination. I was granted admission to the school after a partial payment of the school fees. But we did not have enough to pay for the hostel facilities.

I had dreamt of going to a very good secondary school, living in a boarding house, and enjoying being a student. But I got it all wrong. It was not meant to be. I knew nothing of a boarding house, chop box (the trunks students took to boarding school) with provisions, or even pocket money. For us growing up, pocket money never existed, not that it was ever expected.

After staying in Accra and watching children being driven to and from school, with all the pocket monies and all the pampering, I felt there was something fundamentally wrong. There were children who have never worked for five minutes in their lives insisting on their rights to have all their expectations fulfilled by their fathers, demanding Victoria's Secret underwear and Jimmy Choo's (designer shoes), fully paid for by their "loving" parents. Meanwhile, I often saw anxious parents, desperately looking for ways to make life better for their pampered son who graduated two years earlier and was still looking for a job!

"Ceci," my father called. "You know what," he said, "my cousin Caroline lives near the school. Let us go and talk to her to see if she could find a space for you in her house where you could reside as a day student." I had no option but to follow him. Auntie Caroline and the husband agreed to take me in. We were so thankful and returned home with the good news. I had a little savings from the baby nursing I had done in Accra. My mum added some money to it for me to prepare for school. After a tug-of-war and a long deliberation with his family as to whether I could have it, my father released an old chop box for me to use for school. I appreciated it so much! At that time, there was nothing like a metal trunk in our vocabulary.

\section{Pursuing My Dream of Getting an Education}

On arrival at my Auntie Caroline's house, I found that two other young ladies were already staying with the family. I became the third. They were seniors in the same school I was to attend. Whenever the taps were closed-which was often, especially during dry season or when the village water pressure was low-we had to wake up very early between 3:30 a.m. 
and 4:00 a.m. to go out to look for water before going to school. The closest location where one could get water was over three kilometers away.

We also had to find and fetch firewood for the house. Woe betide us should my Auntie Caroline have to use her money to buy firewood for the house. She would insult me especially, as well as my father, saying how useless he was, how his own family could not even get three square meals a day, and how my poor mother had to fend for my brother and me by herself. It was only my mother who brought foodstuff like yams, cassava dough, and the like to the house on every market day. We went fetching firewood one day in somebody's farm; you can imagine what happened. Our bowls and cutlasses were seized, and we were threatened with the chief's sanction. We pleaded and explained who we were, and as our story was touching, we were released-but without our bowls and cutlasses. Firewood had to be fetched anyway, and so we needed to find another field. We discovered Blue Army Centre, a religious land, a grotto, a special prayer ground for Catholics and non-Catholics alike. We were chased out from that place too. Going out at dawn to fetch firewood became a nightmare, but we had to go. We had to do this at least once a week, and it had to be a weekday, not weekends when farm and landowners would be on their farms and could spot us carrying off their firewood.

Any time we had to go fetching firewood or water, we went to school very late and tired. This coupled with my auntie's insults was not going to help my course, so I discussed the matter with my mother. We thought and deliberated on it, but a hostel could not be an option. The means to afford a hostel or boarding house was out of our league. One good thing was that my desire grew very strong to change my school from the Commercial School to a Technical School, which was one of the choices I had when I passed my Common Entrance examination at elementary Form Four. I succeeded in getting admission into the part-time stream, which meant I could only go to school in the afternoon.

I realized progress had been made at age 17. I saw the method of lecturing was better in the Technical school compared to the Commercial school and made up my mind to attain the highest level of education available for me at the time. I discovered that some subjects that I needed to achieve my aim were not available to part-time students. So once in the school, I started finding ways to get into the full-time stream, which I succeeded in doing after doing one year part-time. This taught me that determination always brings results. I finally became a full-time student of Kpando Technical Institute, a government school. The feeling of 
achievement and satisfaction was even better than when I had to settle for the private Commercial school.

\section{Moving Back to ACCrA}

Immediately after I completed school, I packed my bags and returned home. My mum was happy because the first hurdle was crossed without any casualty. My next line of action was to find work in Accra. I told myself that my lot should be better than my mum's, and I believed at the time that whatever I asked from God, I received. So, with my mother's blessing, I set off for Accra, this time to go live with my mother's elder sister. My auntie and the husband became my parents. But soon after I realized I was an extra mouth in their house to feed, which was not a pleasant thing for them.

Considering the situation, I was torn between staying in Accra to weather the storm and returning home to help my mother farm and support my siblings - just as my father's sister had urged me a year earlier. With all that had happened up to that point, the decision became clear: I stayed on and decided to go to Accra Polytechnic. It was not too difficult for me to get admission into the school, and at the same time I got admission into the School of Languages to study French on a part-time basis. I was determined to occupy myself such that no idle thoughts could disturb me.

\section{Starting on a New Path}

Immediately after earning a diploma certificate, I hit the ground running. I would wake up early in the morning, finish my household chores, and move from office to office looking for a job. After about three months, I got my first job at the West African Examination Council. I counted myself truly blessed when, after an interview, I was informed that I got the job! I started work as the personal assistant to the head of one of the departments. Real life had begun for me-I considered myself an adult worker. I had worked there for one year exactly when I received a letter inviting me for an interview at Standard Chartered Bank. Once again, I was favored by God to be employed after a successful interview. I joined Standard Chartered as a personal assistant to the head of the agriculture department of the bank. 
Determined to keep moving forward, I decided to register for the Chartered Institute of Bankers course, which was the only thing I could consider at that time, as it was a professional course which related to my banking job. My experiences with "The Bank" were indescribable. I call it The Bank because it gave me my most memorable work experiences. After working at the head office for three years, I applied to join the banking stream. This was not difficult to achieve as I did well in the banking course. I worked in various departments at various levels, some very pleasant and some not, especially when I had to work through the night only to come home in the morning to go back the same morning. My work became very tedious at that time because there were technological system upgrades and I needed to make sure things were done appropriately as the manager of the department.

There were good times when I felt I was assured a sustaining and secured job. I could take a loan to do things I could never have done without The Bank, and I made very good friends. My greatest joy was when I received the best Sales and Services Award for the year. The award was presented in cash and presents, like a set of briefcases, which I still keep and am proud of. I suspect the first place Edem, my husband, ever saw me was at the Bank. He was an employee of the Central Bank of Ghana, which was located close to my bank. In 2006, I rose to the level of bank manager. I felt very humbled and fulfilled. My family, mum, and everybody were so proud, happy, and thankful to God.

\section{Nneka Youth Foundation Is Born}

One day in January 2012, while I was on a visit to my small village for an aunt's funeral, I was out and about when more than five girls, aged 12 to 16 years, carrying their babies approached me asking for money. In the evening of the same day, I walked out of my house at around six o'clock and saw boys of the same age openly smoking marijuana. I was upset; I could not sleep the whole of that night. I asked myself, if the situation in my small village could be this chaotic, what could be the situation in the whole district, and in all the rural and deprived communities in my country? I immediately pulled statistics from the Municipal Education Directorate to see what effect these vices were having on education, and I found that of the 3200 youth enrolled in junior high school in the 20102012 academic period, 1142 youth had dropped out of school and over $84 \%$ of these dropouts were a result of these vices. I broke down! 
I had also noticed that young women in their early 40s already had great grandchildren! All of this was very distressing to me. Over the years, there has been a disastrous cycle of teenage pregnancy that has set a huge stumbling block in the path of any worthwhile achievement by the rural folk. This is because they never get the opportunity to fully develop themselves before they begin to have children, which often leads them into child marriages/parenthood. I told myself I had no business sitting behind my desk, calling myself a bank manager, when the human resource base of my community had eroded and was becoming almost nonexistent. I had to do something to break the cycle of teen motherhood.

I started out by supporting orphans in an orphanage by providing food items, toiletries, and medical needs. This I did because I was touched by their plight and the inability of the orphanage to adequately provide for the needs of these children. Eventually, I had to call on Social Welfare to intervene when I realized my support was not going to be sustainable. I was providing support for out-of-school youth by supplying basic school needs for girls, especially to return to school or learn a trade to become self-sufficient.

As a young girl, I strove on my own and left the village for school, and my dreams of becoming a responsible person, of not being a burden on society, became realities. Growing up in a typical rural setting came with many challenges. We were confined to a rustic limiting environment, lacking amenities like electricity and water, not to mention libraries and recreational centers. As an adult, I could see that teenage pregnancy and drug abuse were becoming the norm, and the possibility of a good education was almost nonexistent. My peers in urban communities seemed to have a clearer educational pathway, with learning materials and quality teachers. I observed that the potential of children in rural areas could not be translated into achievement due to very minimal exposure and many more problems. I saw, and continue to see, a major gap between rural and urban communities, and this is the gap I am vigorously seeking to bridge.

In 2012, I went from being a banker to a full-time youth activist. I formed Nneka Youth Foundation to change the mindset of these vulnerable youth, so that they could believe in themselves. They needed to learn that though they came from such deprived communities, they can still become somebody in life; they could become world changers and future leaders if they focused on their education. We have reached over 11,000 children from 200 communities since our inception in 2012, and we have made an incredible impact through the interventions we put in place. 
"Nneka" is an Igbo word meaning, "Mother is Supreme." The name Nneka was discovered in Chinua Achebe's award-winning classic, Things Fall Apart. One character, Okwonkwo, was sent into exile and decided to run to his mother's land. When he was received and welcomed as if there was not any problem, he exclaimed, "Nneka!" The expression is meant to capture the encouragement and security that is available to children in vibrant and united communities. Sadly, this reality remains elusive in underserved regions in Ghana.

Nneka Youth Foundation has made giant strides in changing the lives and mindset of children in 200 rural communities. My passion and experience have come in very handy. When I talk to young people in the communities I work with, they most often express concern about the level of poverty; they lack clothing, food, and, in some cases, shelter; this usually makes them susceptible to all forms of vices, becoming victims of teenage pregnancy, child marriage, and child trafficking. Teenage mothers and vulnerable girls are stigmatized, excluded from school and other social settings, and are subject to abuse and violence by their parents and the men who impregnate them. They lack information on their rights and are unable to engage in any meaningful employment to fend for themselves. Just about all the young people worry about not having educational and employment opportunities. Most young people just want the things that those who are more fortunate have but take for granted: they want to be safe, go to school, have a comfortable life, and build a lasting career. Our biggest challenge is to get the young people we work with to believe in themselves. Someone has to tell these vulnerable children that, Yes! They too can make it, despite the challenges. They too can be as good as anybody in the world and can be the world changers! 
Open Access This chapter is licensed under the terms of the Creative Commons Attribution 4.0 International License (http://creativecommons.org/licenses/ by $/ 4.0 /$ ), which permits use, sharing, adaptation, distribution and reproduction in any medium or format, as long as you give appropriate credit to the original author(s) and the source, provide a link to the Creative Commons licence and indicate if changes were made.

The images or other third party material in this chapter are included in the chapter's Creative Commons licence, unless indicated otherwise in a credit line to the material. If material is not included in the chapter's Creative Commons licence and your intended use is not permitted by statutory regulation or exceeds the permitted use, you will need to obtain permission directly from the copyright holder.

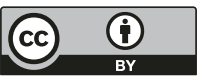

